\title{
EDUKASI MENGENAI PENGGUNAAN ANTIBIOTIK YANG RASIONAL DI LINGKUNGAN SMK NEGERI 1 TAMBELANG BEKASI
}

\author{
Shirly Gunawan ${ }^{1}$, Oentarini Tjandra ${ }^{2}$, dan Susilodinata Halim ${ }^{3}$ \\ ${ }^{1}$ Bagian Farmakologi Fakultas Kedokteran Universitas Tarumanagara, \\ Email: shirlyg@fk.untar.ac.id \\ ${ }^{2}$ Bagian Farmakologi Fakultas Kedokteran Universitas Tarumanagara, \\ Email:oentarinit@fk.untar.ac.id \\ ${ }^{3}$ Bagian Fisiologi, Fakultas Kedokteran Universitas Tarumanagara, \\ Email: drsusilodinata@yahoo.com
}

\begin{abstract}
Antibiotics are antimicrobial drugs used to treat bacterial infections. High prevalence of infectious diseases, increasing the use of antibiotics in society. The high rate of antibiotics use without a doctor's prescription makes their use irrational and leads to drug resistance. One of the factors causing drug resistance is the lack of public knowledge about the use of drugs, especially antibiotics. Knowledge plays an important role in shaping certain beliefs, attitudes, and behaviors. The higher the level of education, it is expected that the better the level of knowledge on drug use. Studies to know the level of knowledge of residents using antibiotics, carried out in SMA and SMK Tambelang District Bekasi Regency, show that most respondents have insufficient knowledge (52.4\%) of antibiotics. For this reason, PKM activities have been carried out in the form of education on the rational use of antibiotics, which was attended by 53 residents in SMK 1 Tambelang Bekasi, consisting of teachers, students, and educational staff. Before and after education, pretest and post-test were carried out to assess knowledge of antibiotics use. The mean pretest score was 8.08 points, and the post-test mean score was 9.42 points. Statistical analysis showed a mean difference between the pretest and post-test values of 1.34 points with a p-value of $0.008(p<0.05)$. With the results obtained, it is expected to increase the knowledge of the residents of SMK 1 Negeri Tambelang Bekasi in the rational use of antibiotics so that it will indirectly reduce the incidence of resistance to antibiotics.
\end{abstract}

Keywords: education, knowledge, antibiotics, rationale

\begin{abstract}
ABSTRAK
Antibiotik merupakan obat golongan antimikroba yang digunakan untuk mengatasi infeksi bakteri. Prevalensi penyakit infeksi yang tinggi, meningkatkan penggunaan antibiotik di masyarakat. Tingginya angka penggunaan antibiotik tanpa resep dokter membuat penggunaannya menjadi irasional dan berdampak pada timbulnya resistensi obat. Salah satu faktor penyebab timbulnya resistensi obat ialah kurangnya pengetahuan masyarakat mengenai penggunaan obat, khususnya antibiotik. Pengetahuan berperan penting dalam membentuk kepercayaan, sikap dan perilaku tertentu. Semakin tinggi tingkat pendidikan, diharapkan semakin baik tingkat pengetahuan terhadap penggunaan obat. Studi tentang tingkat pengetahuan warga dalam penggunaan antibiotik yang telah dilakukan di SMA dan SMK Kecamatan Tambelang Kabupaten Bekasi menunjukkan sebagian besar responden memiliki tingkat pengetahuan buruk $(52,4 \%)$ dalam penggunaan antibiotik. Berdasarkan temuan tersebut, maka dilakukan kegiatan PKM berupa edukasi mengenai penggunaan antibiotik yang rasional. Kegiatan edukasi berupa penyuluhan, dihadiri 53 orang warga di lingkungan SMK 1 Tambelang Bekasi, terdiri dari guru, siswa dan tenaga kependidikan. Sebelum dan sesudah edukasi dilakukan pretest dan post-test untuk menilai pengetahuan tentang pengetahuan dalam penggunaan antibiotik. Rerata nilai pretest sebesar 8,08 poin dan rerata nilai post-test sebesar 9,42 poin. Analisis statistik menunjukkan terdapat perbedaan rerata antara nilai pretest dan post-test sebesar 1,34 poin dengan p-value sebesar 0,008 ( $p<0,05)$. Dengan hasil yang diperoleh ini, diharapkan dapat meningkatkan pengetahuan warga SMK 1 Negeri Tambelang Bekasi dalam penggunaan antibiotik yang rasional, sehingga secara tidak langsung akan mengurangi kejadian resistensi terhadap antibiotik.
\end{abstract}

Kata kunci: edukasi, pengetahuan, antibiotik, rasional

\section{PENDAHULUAN}

Antibiotik merupakan obat golongan antimikroba yang digunakan untuk mengatasi infeksi bakteri. Prevalensi penyakit infeksi yang tinggi, meningkatkan penggunaan antibiotik di masyarakat (Ivoryanto, 2017). Penggunaan obat golongan ini harus dengan resep dokter. Penggunaan antibiotik di negara berkembang seperti Indonesia, seperti halnya di negara maju seperti Amerika Serikat, juga mengalami peningkatan, termasuk penggunaan antibiotik tanpa resep dokter, yang berpotensi terhadap terjadinya resistensi obat (Utami, 2019). 
Data National Academy of Sciences (NAS) Amerika Serikat menunjukkan penggunaan antibiotik meningkat 65\% dari tahun 2000 sampai 2015 (Yulia et al. 2019). The Center for Disease Control and Prevention melaporkan sekitar $30 \%$ peresepan antibiotik yang tidak diperlukan terjadi dari total 262,5 juta peresepan di Amerika pada tahun 2011 (CDC 2019). Sekitar 57,6\% masyarakat di Saudi Arabia juga menggunakan antibiotik tanpa resep (Yulia et al. 2019). Data Riskesdas 2013 menunjukkan 35,2\% masyarakat Indonesia melakukan pengobatan mandiri, dimana 27,8\%-nya adalah antibiotik (Riskesdas 2013). Data tahun 2014 menunjukkan penggunaan antibiotik untuk kasus ISPA serta diare non spesifik cukup tinggi di Puskesmas Kota Bekasi yaitu 29,1 dan 36,7\%. Batas ideal yang ditetapkan Kemenkes untuk penggunaan antibiotik adalah dibawah 20\% (Dinkes Kota Bekasi 2014).

Penggunaan antibiotik berlebihan berpotensi terhadap penggunaan irasional. Hal ini menjadi salah satu faktor penyebab timbulnya resistensi. WHO dalam Antimicrobial Resistence: Global Report on Surveillance menyatakan bahwa kasus resistensi antibiotik tertinggi di dunia terdapat di Asia Tenggara khususnya Staphylococcus aureus resisten metisilin (Kemenkes 2015). Hasil penelitian Antimicrobial Resistant in Indonesia (AMRIN-Study) tahun 2000-2005, menunjukkan sekitar 43\% Escherichia coli resisten terhadap berbagai jenis antibiotik, diantaranya: ampisilin (34\%), kotrimoksazol (29\%) dan kloramfenikol (25\%) (Menkes RI, 2015).

Faktor penting yang menyebabkan tingginya angka resistensi antibiotik ialah penggunaan yang tidak rasional. Pengetahuan masyarakat tentang antibiotik yang minim, dapat memengaruhisikap dan perilaku kesehatan, termasuk dalam penggunaan antibiotik yang tidak rasional. Pengetahuan memiliki peran penting dalam membentuk kepercayaan dan sikap mengenai perilaku tertentu, termasuk perilaku dalam penggunaan antibiotik. Tingkat pendidikan dianggap berpengaruh besar terhadap perilaku tersebut (Ivoryanto, 2017).

Penelitian di Saudi Arabia menunjukkan bahwa mayoritas masyarakat dengan pengetahuan baik dalam penggunaan antibiotik memiliki latar belakang pendidikan S1 (Alqarni et al. 2019). Begitu juga studi di Korea Selatan menunjukkan bahwa masyarakat yang sudah lulus perguruan tinggi 2,39 kali lebih mengerti dalam menggunakan antibiotik dibanding dengan masyarakat yang hanya menempuh sekolah dasar (Kim et al 2011). Penggunaan obat secara benar harus ditanamkan sejak bangku sekolah, sehingga disini guru memiliki peran penting dalam memberikan informasi tentang penggunaan obat yang benar. Penyampaian informasi yang baik oleh pengajar, membuat siswa juga ikut andil dalam menyampaikan informasi kepada orang tua dan masyarakat (Jha et al 2013).

Studi untuk mengetahui tingkat pengetahuan warga dalam penggunaan antibiotik telah dilakukan pada 187 responden di dua SMA/SMK Kecamatan Tambelang Kabupaten Bekasi pada awal tahun 2020. Hasil penelitian menunjukkan sebagian besar responden memiliki tingkat pengetahuan buruk $(52,4 \%)$ dalam penggunaan antibiotik (Handayanti 2020). Berdasarkan temuan tersebut, maka sebagai solusi ialah melakukan edukasi mengenai penggunaan antibiotik yang rasional kepada warga di lingkungan SMK 1 Tambelang Bekasi yang bertujuan untuk meningkatkan pengetahuan dalam penggunaan antibiotik yang rasional, sehingga dapat mencegah timbulnya resistensi terhadap antibiotik.

\section{Pengetahuan dalam Penggunaan Antibiotik}

Pengetahuan merupakan faktor sosial kognitif yang memengaruhi perilaku kesehatan, termasuk perilaku dalam penggunaan antibiotik (Widayati et al. 2012). Terdapat beberapa faktor yang memengaruhi tingkat pengetahuan seseorang, yaitu pendidikan, pekerjaan, pengalaman, keyakinan, dan sosial budaya. Pengetahuan yang baik tentang antibiotik dapat membantu mayarakat dalam menggunakkan antibiotik yang bijak. Kurangnya pengetahuan tentang antibiotik menyebabkan semakin tingginya penggunaan antibiotik sebagai swamedikasi (Kurniawan et al. 
2017). Hasil penelitian di Indonesia Timur menunjukkan adanya hubungan yang bermakna antara tingkat pengetahuan dengan penggunaan antibiotik sebagai swamedikasi. Oleh karena itu, untuk mencegah swamedikasi terhadap antibiotik diperlukan pengembangan pendidikan multi-aspek untuk meningkatkan pengetahuan masyarakat terhadap antibiotik (Kurniawan et al. 2017).

\section{Pengetahuan}

Pengetahuan adalah hasil dari proses penginderaan seperti: penglihatan, pendengaran, penciuman, rasa, serta raba yang sangat dipengaruhi oleh intensitas perhatian persepsi seseorang. Pengetahuan seseorang sangat dipengaruhi oleh sistem indera penglihatan dan pendengaran.

Tingkat pengetahuan seseorang terdiri dari enam tingkatan, yaitu (Notoatmodjo 2014, Kholid 2015):

a. Tahu (Know)

Proses mengingat suatu materi atau rangsang yang telah diterima dan dipelajari dengan lebih spesifik.

b. Memahami (Comprehension)

Kemampuan seseorang dalam menjelaskan serta menguasai suatu objek dengar benar.

c. Aplikasi (Application)

Kemampuan seseorang dalam melaksanakan ataupun mempraktikkan suatu materi yang telah dikuasinya secara benar.

d. Analisis (Analysis)

Kemampuan seseorang dalam menguraikan suatu materi ataupun objek yang saling berhubungan satu dengan yang lainnya.

e. Sintesis (Synthesis)

Kemampuan seseorang dalam menyusun dan menggabungkankan suatu bagian dengan bagian lainnya sehingga terbentuk suatu idea atau gagasan baru.

f. Evaluasi (Evaluation)

Berhubungan dengan pengetahuan seseorang dalam membandingkan suatu objek berdasarkan standar yang telah ditentukan.

Faktor-faktor yang memengaruhi pengetahuan, antara lain (Masturah 2018):

a. Faktor pendidikan

Memiliki peran besar dalam pengetahuan seseorang. Seseorang dengan latar belakang pendidikan yang tinggi akan lebih cepat, paham, serta tanggap mengenai suatu hal yang baru didapatkan sehingga mudah untuk mengaplikasikan dikehidupan sehari-hari.

b. Faktor pekerjaan

Pekerjaan juga memengaruhi pengetahuan seseorang dalam menggali informasi yang ingin diketahuinya.

c. Faktor pengalaman

Pengetahuan seseorang juga dipengaruhi oleh pengalaman yang dimilikinya, dengan pengalaman yang banyak tentang suatu hal akan memungkinkan seseorang juga memiliki pengetahuan yang banyak pula mengenai hal tersebut.

d. Keyakinan

Keyakinan yang dimiliki seseorang mengenai suatu hal ataupun objek tertentu dapat memengaruhi pengetahuan terhadap suatu hal tersebut

e. Sosial budaya

Kebiasan seseorang berkaitan dengan kebiasaan dan kebudayaan yang di anut oleh keluarganya sehingga akan memengaruhi sikap dan perilaku seseorang. 
Pengetahuan dapat diperoleh dengan berbagai cara, meliputi (Kholid 2015):

1. Cara tradisional

a. Cara coba salah (trial and error)

Digunakan sejak dahulu, sebelum adanya kebudayaan. Cara ini menggunakan peluang untuk menyelesaikan atau mengatasi suatu masalah.

b. Cara kekuasaan atau otoritas

Informasi yang didapatkan dari pendapat orang lain yang belum diketahui kebenarannya, hanya berdasarkan pikiran sendiri namun dianggap sebagai sesuatu yang benar.

c. Berdasarkan pengalaman pribadi

Pengalaman suatu faktor yang memengaruhi pengetahuan seseorang. Untuk dapat menyelesaikan suatu masalah maka seseorang harus mengulang kembali pengalamannya terdahulu.

d. Melalui jalan pikiran

Setelah seseorang mendapatkan suatu informasi, mereka akan memakai jalan pikirannya untuk memproses apakah informasi yang didapatkan adalah benar.

\section{Cara modern}

Untuk mendapatkan informasi yang lebih sistematik serta baik, seseorang akan melakukan pengamatan mengenai fakta-fakta yang berhubungan dengan informasi yang didapatkannya.

\section{Pendidikan Kesehatan}

Pendidikan merupakan suatu proses pembelajaran yang sangat berkaiatan dengan pengetahuan dan kesadaran seseorang agar dapat melakukan suatu tindakan guna meningkatkan taraf kesehatannya. Pendidikan/ edukasi kesehatan adalah suatu upaya dalam membentuk perilaku masyarakat agar dapat memberikan hasil yang diinginkan agar sesuai dengan yang diharapkan dan berkaitan dengan kesehatan. Tujuan akhir dari pendidikan kesehatan yaitu agar masyarakat dapat mengaplikasikan hidup sehat. Pendidikan/ edukasi merupakan faktor terpenting dalam memotivasi penggunaan antibiotik secara bijak. Latar belakang pendidikan yang baik memengaruhi tingkat pengetahuan yang dimiliki juga akan semakin baik sehingga memiliki sikap dan perilaku yang baik.

\section{Upaya Peningkatan Pengetahuan dalam Penggunaan Antibiotik}

Kegiatan PKM berupa edukasi mengenai penggunaan antibiotik yang rasional kepada warga sekolah merupakan upaya tindak lanjut nyata dari temuan hasil penelitian yang telah dilakukan sebelumnya, dimana diketahui masih kurangnya tingkat tingkat pengetahuan dalam penggunaan antibiotik yang rasional di lingkungan SMA/SMK Kecamatan Tambelang Kabupaten Bekasi.

Target sasaran PKM adalah seluruh warga di lingkungan SMK Negeri 1 Tambelang Kabupaten Bekasi, termasuk staf pengajar, siswa, tenaga kependidikan dan non-kependidikan, terutama para guru. Dengan meningkatnya pengetahuan guru dalam penggunaan antibiotik yang rasional, maka akan dapat meneruskan informasi yang benar kepada para siswa dan masyarakat di sekitarnya, karena guru memiliki peran penting dalam proses pendidikan yang dilakukan di lingkungan sekolah maupun lingkungan sosial masyarakat. Kebiasaan penggunaan obat secara benar dan rasional harus ditanamkan sejak dini. Penyampaian informasi yang tepat oleh pengajar, membuat siswa juga ikut andil dalam menyampaikan informasi kepada orang tua dan masyarakat.

Sekolah Menengah Kejuruan (SMK) Negeri 1 Tambelang Bekasi yang berdiri di atas lahan seluas $15.000 \mathrm{~m}^{2}$ ini, memiliki populasi warga yang cukup besar. Sekolah ini memiliki 70 orang staf pengajar dan tenaga kependidikan akademik dan non-akademik. SMKN 1 Tambelang memiliki 5 
bidang studi atau jurusan yaitu: Teknik Instalasi Listrik (TIL), Teknik Elekronika Industri (TEI), Teknik Audio Video (TAV), Teknik Kendaraan Ringan (TKR), dan Teknik Komputer Jaringan (TKJ) dengan jumlah siswa sekitar 1000 siswa. Sekolah ini jaktif dalam menyelenggarakan kegiatan yang sifatnya ekstrakurikuler. Selain kegiatan pengembangan di bidang olahraga dan seni, juga banyak melakukan kerja sama dengan berbagai pihak untuk mengadakan kegiatan yang melibatkan narasumber dari luar dalam rangka meningkatkan wawasan warganya, seperti edukasi anti narkoba dan sebagainya. Kehadiran SMKN 1 Tambelang diharapkan dapat meningkatkan kemampuan dalam mencapai sumber daya manusia yang handal dan mumpuni.

\section{METODE PELAKSANAAN PKM}

Berdasarkan masalah yang ada, maka maka Tim Pengabdian Kepada Masyarakat (PKM) Fakultas Kedokteran Universitas Tarumanagara (FK Untar), sebagai salah satu perwujudan Tridharma Perguruan Tinggi, mengadakan kegiatan edukasi di SMK Negeri 1 Tambelang Bekasi pada tanggal 16 Desember 2020 secara daring melalui aplikasi platform zoom. Untuk sosialisasi kegiatan ini, dilakukan penyebaran informasi kegiatan melalui leaflet yang didistribusikan di lingkungan SMK Negeri 1 Tambelang (Gambar 1). Sebelum dan sesudah penyampaian materi edukasi, dilakukan pretest dan post-test bagi peserta untuk menilai pengetahuan dalam penggunaan antibiotik yang rasional. Selanjutnya dilakukan analisis $t$-test untuk mengukur perbedaan rerata pengetahuan sebelum dan setelah edukasi. Sebagai narasumber adalah tiga orang dosen Fakultas Kedokteran Universitas Tarumanagara yang dibantu dua orang mahasiswa.

\section{Gambar 1}

\section{Sosialisasi kegiatan PKM}

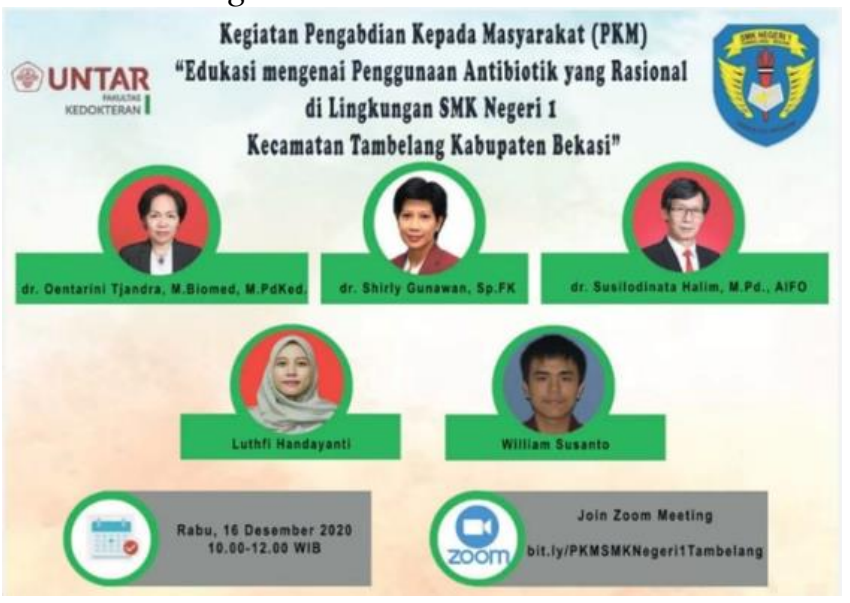

\section{HASIL DAN PEMBAHASAN}

Kegiatan PKM ini dihadiri oleh 53 peserta. Target peserta kegiatan PKM kurang tercapai. Dari yang ditargetkan 70 peserta (sesuai dengan data pendaftaran ulang sebelum kegiatan), ternyata peserta yang hadir hanya 53 orang yaitu guru sebanyak 32 orang (60,38\%), 17 orang siswa $(32,07 \%)$ dan 4 orang karyawan $(7,55 \%)$. Kurang tercapainya target peserta disebabkan sebagian peserta terkendala dengan masalah jaringan internet. Lokasi kecamatan Tambelang Bekasi terbilang cukup jauh dari pusat kota. Sebagian warga, baik guru, karyawan dan siswa SMK Negeri 1 Tambelang, tinggal di daerah dengan jaringan internet yang kurang baik. Selain itu sebagian besar siswa juga mengalami kendala dengan kuota internet, sehingga tidak dapat mengikuti kegiatan PKM yang diadakan secara daring, walaupun sebelumnya telah mendaftarkan diri untuk ikut kegiatan ini. 
Kisaran usia peserta yang hadir pada kegiatan ini ada 20 orang berusia di antara 31-40 tahun $(37,74 \%), 17$ orang berusia $11-20$ tahun $(32,08 \%), 10$ orang berusia $41-50$ tahun $(18,87 \%), 5$ orang berusia 21-30 tahun (9,43\%), dan 1 orang berusia 51-60 tahun (1,89\%). Latar belakang pendidikan terakhir peserta sebagian besar S1 ada 33 orang (62,26\%), 15 orang SMP (28,3\%), 3 orang SMA $(5,66 \%)$, D3 dan S2 masing-masing 1 orang (1,89\%). Karakteristik peserta kegiatan PKM dapat dilihat pada Tabel 1.

\section{Tabel 1}

Karakteristik Peserta Kegiatan PKM

\begin{tabular}{lcc}
\hline Keterangan & $\begin{array}{c}\text { Jumlah } \\
(\mathbf{n = 5 3})\end{array}$ & Persentase (\%) \\
\hline Jenis Kelamin & & \\
Laki-laki & 31 & 58,49 \\
Perempuan & 22 & 41,51 \\
Usia & & \\
$11-20$ & 17 & 32,08 \\
$21-30$ & 5 & 9,43 \\
31-40 & 20 & 37,74 \\
$41-50$ & 10 & 18,87 \\
51-60 & 1 & 1,89 \\
Tingkat Pendidikan & & \\
SMP & 15 & 28,30 \\
SMA & 3 & 5,66 \\
D3 & 1 & 1,89 \\
S1 & 33 & 62,26 \\
S2 & 1 & 1,89 \\
Pekerjaan & & \\
Guru & 32 & 60,38 \\
Karyawan & 4 & 7,55 \\
Siswa & 17 & 32,08 \\
& & \\
\hline
\end{tabular}

Pada kegiatan ini dilakukan pretest sebelum pemaparan materi edukasi dan post-test untuk menilai perubahan pengetahuan peserta sesudah narasumber menyampaikan materi. Tingkat pengetahuan responden pada penelitian ini dinilai berdasarkan hasil jawaban responden dalam kuesioner mengenai pengetahuan dalam penggunaan antibiotik sebanyak 15 butir pernyataan dengan pilihan jawaban benar dan salah (Tabel 2). Kuesioner ini telah dianalisa berdasarkan 7 indikator berdasarkan pedoman penggunaan obat rasional yang meliputi pengetahuan berdasarkan indikasi penggunaan antibiotik, dosis antibiotik, interval waktu penggunaan antibiotik, cara pemberian antibiotik, lama pemberian antibiotik, efek samping antibiotik, dan informasi mengenai antibiotik. Hasil penilaian menunjukkan rerata nilai pretest peserta PKM sebesar 8.08 poin dan rerata nilai post-test sebesar 9,42 poin (Tabel 3).

\section{Tabel 2}

Soal Pretest/ Post-Test

\begin{tabular}{ll}
\hline No. & \multicolumn{1}{c}{ Pertanyaan/ Jawaban } \\
\hline 1. Antibiotik merupakan golongan obat yang digunakan untuk mengobati penyakit infeksi yang disebabkan oleh \\
bakteri. (B) \\
2. Antibiotik merupakan golongan obat yang digunakan untuk mengobati penyakit infeksi yang disebabkan oleh \\
virus. (S) \\
3. Antibiotik merupakan golongan obat yang digunakan untuk mengobati penyakit infeksi yang disebabkan oleh \\
jamur. (S) \\
4. Antibiotik digunakan untuk mengobati gejala penyakit. (S) \\
5. Paracetamol merupakan obat yang berperan sebagai antibiotik. (S)
\end{tabular}




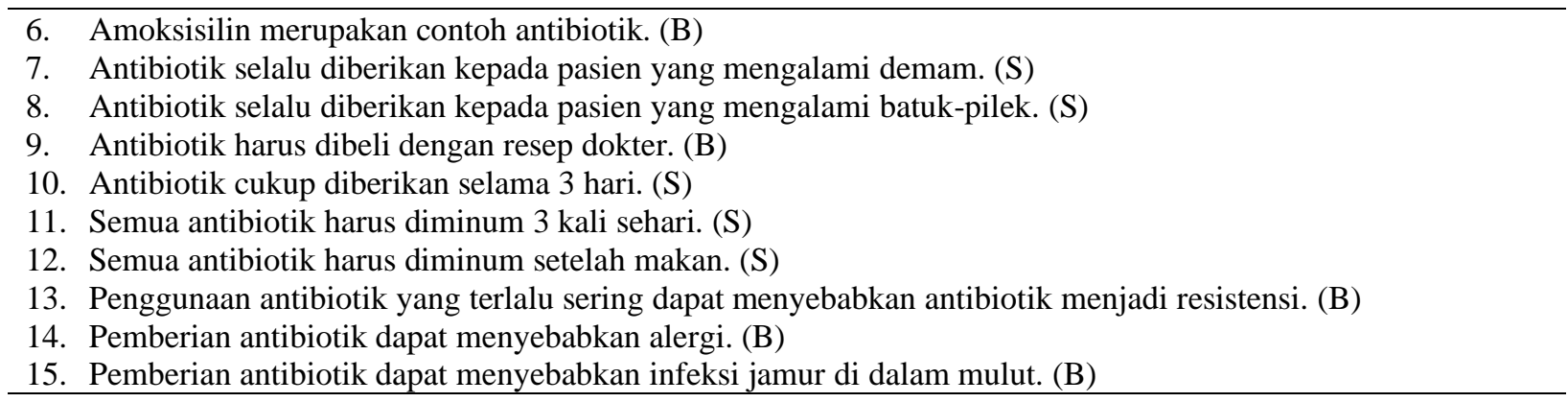

Tabel 3

Rerata Nilai Pretest/Post-Test

\begin{tabular}{lcc}
\hline Variabel & Mean \pm SD & Median (min-maks) \\
\hline Rerata nilai pretest $(\mathrm{n}=53)$ & $8,08 \pm 2,23$ & $8,5(2-11)$ \\
Rerata nilai post-test $(\mathrm{n}=53)$ & $9,42 \pm 2,06$ & $10(4-12)$ \\
\hline
\end{tabular}

\section{Tabel 4}

Hasil Paired Sample T-Test

\begin{tabular}{lccc}
\hline & Mean difference \pm SD & 95\% CI & p-value \\
\hline Post-test - pretest & $-1,35 \pm 2,37$ & $-2,30--0,39$ & 0,008 \\
& & & \\
\hline
\end{tabular}

Hasil analisis statistik menunjukkan terdapat perbedaan rerata antara nilai pretest dan post-test sebesar 1,34 poin dengan $p$-value sebesar $0.008(\mathrm{p}<0,05)$, yang artinya ada perbaikan pengetahuan pasca edukasi. Hasil analisis menunjukkan secara statistik bermakna. Hasil paired sample t-test dapat dilihat pada Tabel 4.

\section{KESIMPULAN DAN SARAN}

Pelaksanaan kegiatan PKM "Edukasi mengenai penggunaan antibiotik yang rasional di lingkungan SMK Negeri 1 Kecamatan Tambelang Kabupaten Bekasi" dapat terlaksana dengan baik. Program yang dilakukan FK Untar ini telah melibatkan partisipasi aktif 53 warga di lingkungan sekolah tersebut.

Peserta kegiatan ini Sebagian besar adalah guru, sebanyak 32 orang $(60,38 \%)$, dengan kelompok usia terbanyak yaitu 31-40 tahun (37,74\%). Latar belakang pendidikan sebagian besar peserta adalah S1 sebanyak 33 orang $(62,26 \%)$. Tingkat pengetahuan responden pada penelitian ini dinilai berdasarkan perbaikan hasil jawaban dalam post-test dibandingkan dengan pretest. Rerata nilai pretest sebesar 8.08 poin dan nilai post-test sebesar 9.42 poin. Analisis statistik menunjukkan terdapat perbedaan rerata antara nilai pretest dan post-test sebesar 0.45 poin dengan $p$ value sebesar 0.003 ( $\mathrm{p}<0.005$ ). Hal ini menunjukkan ada perbaikan pengetahuan pasca edukasi.

Kegiatan edukasi mengenai penggunaan antibiotik yang rasional di SMK Negeri 1 Tambelang Bekasi merupakan upaya yang bijak dalam rangka mendukung penggunaan obat yang rasional, khususnya penggunaan antibiotik pada warga sekolah tersebut. Penggunaan antibiotik secara rasional akan mengurangi terjadinya kasus resistensi obat. Kegiatan PKM ini akan menambah wawasan serta pengetahuan dalam penggunaan antibiotik yang rasional bagi guru, tenaga kependidikan dan siswa. Program yang melibatkan kerja sama FK Untar dengan SMK Negeri 1 Tambelang Bekasi ini dapat menjadi awal yang baik untuk kerja sama, khususnya pengembangan program kesehatan selanjutnya di masa mendatang. 


\section{Gambar 2}

\section{Materi edukasi}

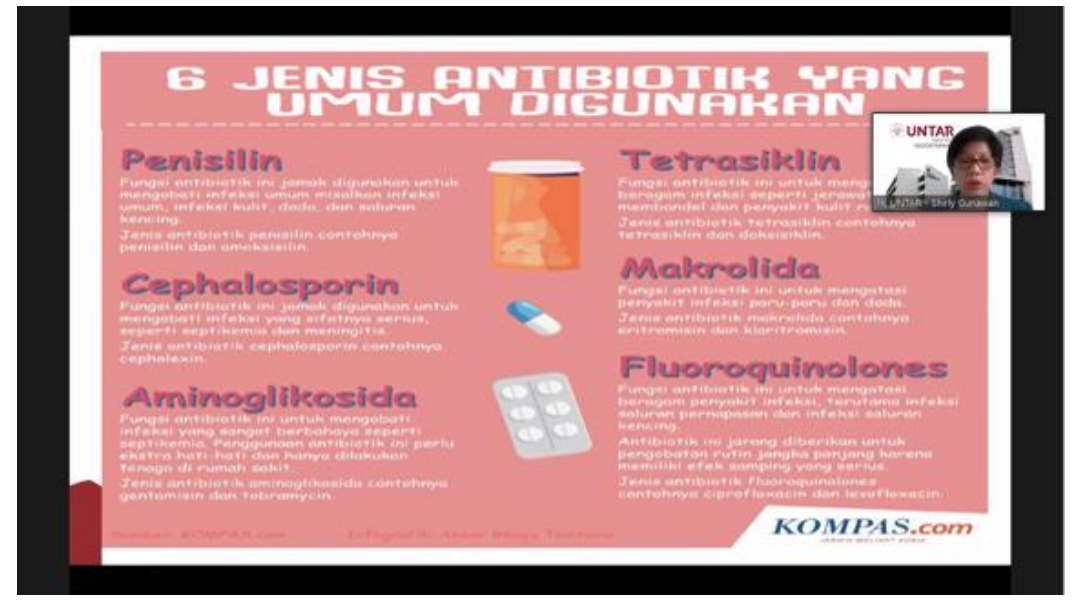

\section{Gambar 3}

\section{Kegiatan PKM melalui zoom}

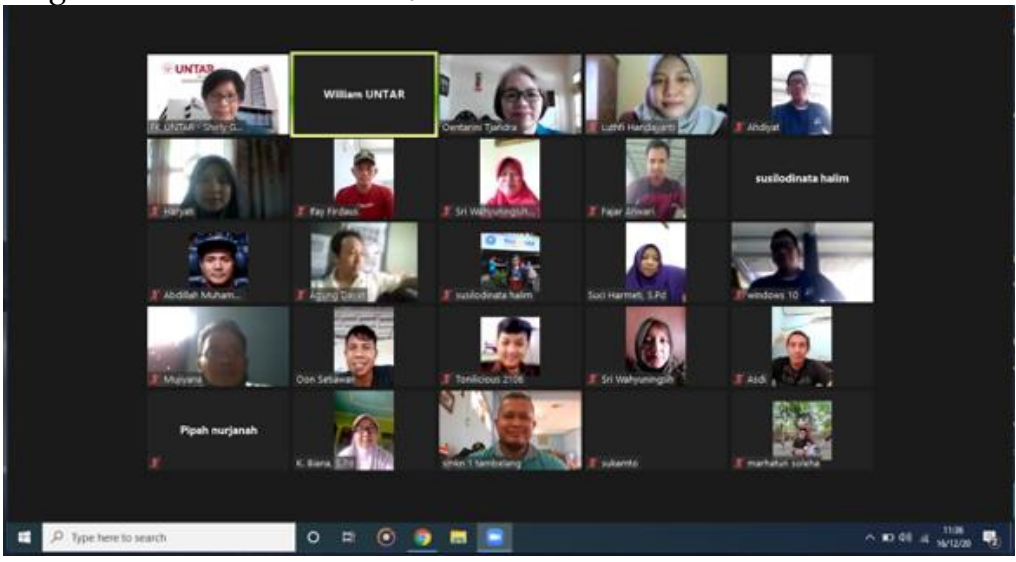

\section{Ucapan Terima Kasih (Acknowldgement)}

Tim PKM mengucapkan terima kasih kepada Rektor Universitas Tarumanagara beserta jajaran, Lembaga Penelitian dan Pengabdian Masyarakat Univeristas Tarumanagara atas dukungan pendanaan untuk terlaksananya kegiatan pengabdian kepada masyarakat ini. Tim juga mengucapkan terima kasih kepada Pimpinan Fakultas Kedokteran Universitas Tarumanagara beserta jajaran atas dukungannya mulai dari persiapan hingga pelaksanaan kegiatan PKM ini. Tak lupa terima kasih kepada pimpinan, para guru, tenaga kependidikan dan siswa SMK 1 Negeri Kecamatan Tambelang Kabupaten Bekasi atas dukungan dan partisipasinya dalam kegiatan ini.

\section{REFERENSI}

Alqarni, A. S., \& Abdulhari, M. (2019). Knowledge and attitude towards antibiotic use within consumers in Alkharj, Saudi Arabia. Saudi Pharmaceutical Journal, 106-111.

CDC. (2018). Antibiotic use in the United States, 2018 update: Progress and opportunities. Atlanta, GA: US Departement of Health and Human Services, CDC.

Dinas Kesehatan Kota Bekasi. (2014). Profil Kesehatan Kota Bekasi, Jawa Barat, 2014.

Handayanti, L., \& Gunawan, S. (2021). Hubungan tingkat pendidikan dan pengetahuan dalam penggunaan antibiotika di lingkungan SMA/SMK Kecamatan Tambelang Kabupaten Bekasi. Tarumanagara Medical Journal, 3(2), 337-343. 
Ivoryanto, E., Sidarta, B., \& Illahi, R. K. (2017). Hubungan tingkat pendidikan formal masyarakat terhadap pengetahuan dalam penggunaan antibiotika oral di Apotek Kecamatan Klojen. Pharmaceutical Journal of Indonesia, 2(2), 31-36.

Jha, N., Bajracharya, O., \& Shankar, P. R. (2013). Knowledge, attitude, and practice toward medicines among school teacher in Lalitpur district, Nepal before and after an educational intervention. BMC Public Health, 13, 652. https://doi.org/10.1186/1471-2458-13-652

Kementerian Kesehatan Republik Indonesia. (2013). Riset Kesehatan Dasar (RISKESDAS).

Kementerian Kesehatan Republik Indonesia. (2015). Penggunaan antibiotik bijak dan rasional kurangi beban penyakit infeksi. Jakarta, Indonesia. https://www.depkes.go.id/article/vies/15081100001.

Kholid, A. (2015). Promosi kesehatan dengan pendekatan teori perilaku, media, dan aplikasinya. Edisi 1. Rajawali Pers.

Kim, S. S., Moon, S., \& Kim, E. J. (2011). Public knowledge and attitudes regarding antibiotic use in South Korea. $J$ Korean Acad Nurs, 41(6), 742-749. https://doi.org/10.4040/jkan.2011.41.6.742.

Menteri Kesehatan Republik Indonesia. (2015). Peraturan Menteri Kesehatan Republik Indonesia Nomor 2406 / MENKES / PER / XII / 2015 tentang pedoman umum penggunaan antibiotik. Menteri Kesehatan. Jakarta.

Kurniawan, Posangi, J., Rampengan N.(2017). Association between public knowledge regarding antibiotics and self-medication with antibiotics in telling Atas Community Health Center, East Indonesia. :Medical Journal of Indonesia, 26(1), 62-9. https://doi.org/10.13181/mji.v26i1.1589

Masturah, I, \& Anggita, N.(2018). Metodologi penelitian kesehatan. Edisi 1. Kementerian Kesehatan Republik Indonesia.

Notoatmodjo, S. (2014). Promosi kesehatan teori dan aplikasi. Rineka Cipta.

Utami, R. (2011). Antibiotik, resistensi dan rasionalitas terapi. El Hayah, 1(4), 191-198.

Widayati, A., Suryawati, S., Crespigny, C., \& Hiller, J.(2012). Knowledge and beliefs about antibiotics among people in Yogyakarta City Indonesia: a cross sectional population-base survey. Antimicrobial Resistence Infection Control, 1-38.

Yulia, R., Putri, R., Wahyudi, R. (2019). Studi tingkat pengetahuan Masyarakat terhadap penggunaan antibiotik di Puskesmas Rasimah Ahmad Bukittinggi. Journal of Pharmaceutical and Sciences (JPS), 2(2), 43-48. 